(2) Open Access Full Text Article

ORIGINAL RESEARCH

\title{
Immunogenicity and Efficacy of Insulin Glargine Biosimilar Ezelin versus Originator Insulin Glargine in Patients with Type 2 Diabetes
}

This article was published in the following Dove Press journal: Diabetes, Metabolic Syndrome and Obesity: Targets and Therapy

Tri Juli Edi Tarigan'

Adisti Dwijayanti ${ }^{2}$

Susie Setyowati ${ }^{3}$

Melva Louisa $\mathbb{D}^{4}$

'Division of Endocrinology and Metabolism, Department of Internal Medicine, Dr. Cipto Mangunkusumo National Referral Hospital, Faculty of Medicine, Universitas Indonesia, Jakarta, Indonesia; ${ }^{2}$ Department of Medical Pharmacy, Faculty of Medicine,

Universitas Indonesia, Jakarta, Indonesia; ${ }^{3}$ Division of Endocrinology, Department of Internal Medicine, Gatot Soebroto Presidential Hospital, Jakarta, Indonesia; ${ }^{4}$ Department of Pharmacology and Therapeutics, Faculty of Medicine, Universitas Indonesia, Jakarta, Indonesia
Purpose: To compare the immunogenicity and efficacy of insulin glargine biosimilar Ezelin (EZL) versus originator insulin glargine Lantus (LAN) as a reference basal insulin in patients with type 2 diabetes (T2D).

Patients and Methods: This was a randomized, multicenter, open-label, 24-week study in insulin-naïve patients with $\mathrm{T} 2 \mathrm{D}$, with $\mathrm{HbA} 1 \mathrm{c}$ of $>7.0 \%$. We randomly assigned 133 eligible patients to receive either EZL or LAN. Baseline characteristics, including insulin autoantibody (IAA), zinc transporter 8 (ZnT8) antibody, HbA1C, fasting plasma glucose (FPG), 2-hour postprandial plasma glucose (2hPPG), AST, ALT, BUN, eGFR, and oral antidiabetic drugs, were obtained before starting insulin treatment. After starting treatment, insulin dose was titrated to achieve FPG target along with oral antidiabetic drugs. Patients were given home glucometer and assisted to record plasma glucose measurement and adverse event (AE). Every month, patients came to the diabetes clinic and performed a regular physical examination and intensifying treatment if needed. Out of the 133 randomized patients, only 122 completed the study and can be examined for their IAA and ZnT8 after 6 months of treatment. The study was registered in clinicaltrials.gov, NCT03352674.

Results: There is a similar proportion of patients with changes of IAA from baseline: 1 out of $58(1.7 \%)$ patients receiving EZL versus 1 out of $64(1.6 \%)$ patients receiving LAN ( $p=$ 1.000). One patient in the EZL group (1.7\%) versus none in the LAN group experienced a change of ZnT8 antibody from baseline. Similar glucose control in EZL versus LAN was determined by the change in HbA1c, FPG, and $2 \mathrm{hPPG}(-2.0 \%,-67.46 \mathrm{mg} / \mathrm{dL}$, and $-76.51 \mathrm{mg} / \mathrm{dL}$ in the EZL group versus $-1.7 \%,-58.11 \mathrm{mg} / \mathrm{dL}$, and $-70.03 \mathrm{mg} / \mathrm{dL}$ in the LAN group). There were six events of documented hypoglycemia in the EZL group versus five events in the LAN group. No patients experienced diabetic ketoacidosis during the study.

Conclusion: Overall, insulin glargine biosimilar EZL and originator insulin glargine LAN have shown a similar immunogenicity profile, as well as efficacy in providing glucose control and safety findings in T2D populations.

Keywords: biosimilar, insulin autoantibody, zinc transporter 8 antibody, hyperglycemia

\section{Introduction}

Type 2 diabetes (T2D) is a condition in which pancreatic beta cells undergo progressive failure, which means that most patients will eventually need insulin treatment. ${ }^{1-3}$ Available treatment guidelines recommend that the use of insulin is started when lifestyle interventions and oral antidiabetic drugs failed to achieve HbAlc of $<7 \%$.
Correspondence: Tri Juli Edi Tarigan Division of Endocrinology and Metabolism, Department of Interna National Referral Hospital, Faculty of Medicine, Universitas Indonesia, Jakarta, Indonesia

Tel +62 21-3907703

Email tri.judi@ui.ac.id

Diabetes, Metabolic Syndrome and Obesity: Targets and Therapy 2021:14 107-II6 
However, there were evidences supporting the earlier use of insulin therapy to prevent diabetes complication and protect beta cell function, thus interrupting the disease progression. ${ }^{5}$

Insulin glargine is a biosynthetic analog of insulin, providing 24-hour blood glucose controls without any significant peak changes. ${ }^{3,4,6}$ LAN is the first insulin glargine available in the market. Biosimilar products are approved copies available of biological products that have already received a marketing authorization. ${ }^{7}$ In the world, several biosimilar insulin products have been granted marketing authorization, such as insulin glargine LY2963016 (Basaglar), insulin glargine MK-1293, Mylan's insulin glargine, and Lispro insulin SAR342434. Insulin preparations are still one of the drugs that is frequently used in patients with T2D. Biosimilar insulin is expected to broaden therapeutic options in patients with diabetes and reduce health costs. ${ }^{8}$

Ezelin (EZL) is an insulin glargine produced by Gan \& Lee Pharmaceutical Ltd. or known in its home country as Basalin. $^{9,10}$ In Indonesia, EZL has obtained marketing authorization as biosimilar insulin glargine. EZL has proven its efficacy and safety in the previous clinical trial compared to the originator insulin glargine, which is Lantus (LAN). ${ }^{9}$ To be able to replace its originator insulin product, the requirements that must be fulfilled by biological products are their similar efficacy, safety, and potential for immunogenicity. ${ }^{7,11,12}$ Biological products, especially biosimilar, have the potential to cause an immunogenic response and may affect the efficacy and safety profile of the drug. ${ }^{7}$ Therefore, we conducted the present study to compare the immunogenicity of EZL as compared to LAN in patients with T2D. In addition to immunogenicity, the efficacy and safety of both glargine preparations were also assessed.

\section{Patients and Methods}

\section{Study Design and Patients}

This was a multicenter, two-arm, active-control, open-label, parallel assignment, randomized, controlled trial in patients with T2D to evaluate the immunogenicity and efficacy of insulin EZL versus LAN. The study was conducted from July 2016 to December 2018 in three hospitals in Jakarta, Indonesia. We planned to recruit 120 eligible patients, with 60 patients in each treatment arm.

The study was approved by the Ethics Committee of the Faculty of Medicine Universitas Indonesia and was conducted in compliance with the Declaration of Helsinki and ICH-GCP guidelines. All patients gave written informed consent prior to their participation in the study. This study was registered in clinicaltrials.gov, NCT03352674.

Eligible patients with T2D have HbA1c of $>7.0 \%$, who received two or more oral antidiabetics, insulin-naïve, and have BMI at the range of $19-35 \mathrm{~kg} / \mathrm{m}^{2}$. Patients of childbearing age were asked to use contraception during the study. The exclusion criteria of patients include the history of repeated ketoacidosis (more than twice in the last 12 months), history of pancreatectomy, eGFR of $<30 \mathrm{~mL} / \mathrm{min} /$ $1.73 \mathrm{~m}^{2}$, positive baseline zinc transporter 8 (ZnT8) antibody, treated with glucocorticoid, and immunosuppressant of cytostatic 60 days before the start of the study. Patients were also excluded if they have a history of any kind of malignancy and drug or alcohol abuse. They were known to have hypersensitivity reactions to insulin glargine or its excipients.

\section{Method}

Patients were randomized to receive either EZL or LAN (both in the form of 100 units per $\mathrm{mL}$ ) subcutaneous injection, once daily, for 6 months. At the time of randomization, patients were trained and given a pocketbook regarding insulin injection techniques. The dose was started with 0.2 units/kg body weight (BW)/day. Patients were instructed to check fasting self-monitored blood glucose (SMBG) every 3 days and report it to the investigator. The SMBG was used by the investigator to adjust the insulin dose timely. The dose of EZL or LAN was adjusted 2-4 units until patients achieved fasting SMBG of $80-<130 \mathrm{mg} / \mathrm{dL}$.

\section{Endpoints}

The primary endpoint was the immunogenicity of EZL versus LAN by determining the proportions of patients who underwent the change of insulin autoantibodies (IAA) and the ZnT8 from negative to positive after 6 months of treatment.

The secondary endpoints include the safety and efficacy of EZL versus LAN by evaluating the change of HbA1c, fasting plasma glucose (FPG), and 2-hour postprandial plasma glucose (2hPPG), after 24-week of treatments as compared with baseline HbAlc. The response rates of patients achieving $\mathrm{HbAlc}$ of $<7.0 \%$ after 3 and 6 months of treatments, the dose of insulin/ $\mathrm{kg} \mathrm{BW/day} \mathrm{at} \mathrm{the} \mathrm{end} \mathrm{of} \mathrm{treatment,} \mathrm{and} \mathrm{the} \mathrm{change} \mathrm{of}$ BW were also determined.

Safety information, including hypoglycemia, ketoacidosis, and data on adverse events (AEs), was collected at each visit and during the final assessment. The rates of serious adverse events (SAEs) were also recorded. 
A blood sample for the analysis of IAA and ZnT8 was collected at the study initiation and at the end of 24-week treatment. IAA was determined using an enzyme-linked immunoassay (ELISA) kit (Cusabio), whereas ZnT8 antibodies were measured using ZnT8 (slc30a8) autoantibody ELISA kit (MBS706849). The results of IAA and ZnT8 were qualitatively presented, as negative or positive. The optical density (OD) of the sample was compared to the OD of the control provided by the kit. Samples were considered positive if the OD sample was $\geq$ cutoff value.

$\mathrm{HbA1c}, \mathrm{FPG}$, and $2 \mathrm{hPPG}$ were measured before the start of treatment, after 12 and 24 weeks.

Hypoglycemia was defined as SMBG of $\leq 70 \mathrm{mg} / \mathrm{dL}$. A hypoglycemia event was considered severe, regardless of blood glucose level measurement, if patients required another person's assistance.

\section{Statistical Analysis}

Safety analysis was performed in the intention-to-treat population, which included all patients who received at least one dose of study drugs (safety population). Efficacy analysis was done using prespecified per-protocol analysis, which provides for patients with evaluable pre- and postmeasurement of IAA or ZnT8, which can be included for efficacy analysis (efficacy population). Numeric data were presented in mean (SD) or median (min-max), depending on the normality and homogeneity of the data. Categorical data were reported in percentages. The difference of means between the two groups was analyzed using unpaired $t$-test if qualified for parametric test or Mann-Whitney $U$-test for the nonparametric test. The difference in proportions between the two groups was analyzed using the chisquare or Fisher's exact test. Statistically significant differences between groups were determined with $\mathrm{p}<0.05$.

\section{Results}

\section{Patient Disposition and Baseline Characteristics}

The flow of patients throughout the study is presented in Figure 1. Out of the 171 patients screened for eligibility, 133 patients met eligibility criteria and further randomized to receive drug treatment. The 133 patients receiving drug treatments were further referred to as the safety population. In the EZL group, six patients did not complete the study, and one patient was excluded from the analysis.

In contrast, in the LAN group, two patients did not complete the study, and two patients were excluded from the analysis. The total number of patients analyzed for the primary endpoint was 58 in the EZL group and 64 in the LAN group; this is referred to as the efficacy population. Patients who did not complete the study or have incomplete data of IAA and ZnT8 were not included for the primary endpoint analysis; however, they were still included in the safety analysis. Therefore, the numbers of subjects for the immunogenicity analysis were 122 . However, all of the randomized patients $(n=133)$ were included in the safety analysis (Figure 1).

Demographic and baseline characteristics were generally similar between the two groups in terms of glucose control, markers of liver functions, kidney functions, and oral antidiabetic drugs used at baseline (Table 1).

\section{Primary Endpoints}

The primary endpoints were the immunogenicity markers. The proportions of patients with IAA change from baseline were similar between the two groups. Only $1(1.7 \%)$ out of 58 patients received EZL and 1 (1.6\%) out of 64 patients received LAN. Only one patient experienced a change of ZnT8 from negative to positive and none in the LAN group (Table 2).

\section{Secondary Endpoints}

The mean change of $\mathrm{HbAl}$, FPG, and $2 \mathrm{hPPG}$ is presented in Table 3. The results of HbA1c, FPG, and 2hPPG after 12 and 24 weeks of treatment are given in Figure 2. Similar glucose control was achieved in patients receiving EZL with a change in $\mathrm{HbA1c}$ of $-2.0 \%$, whereas there was a $-1.69 \%$ change in $\mathrm{HbA} 1 \mathrm{c}$ in patients receiving LAN. No difference was found in the change of FPG and 2hPPG. In the EZL group, the change in FPG and 2hPPG is relatively high $(-67.46$ and $-76.51 \mathrm{mg} / \mathrm{dL}$, respectively), whereas in the LAN group, it was -58.11 and $-70.03 \mathrm{mg} / \mathrm{dL}$, respectively (Figure 2). The proportions of patients achieving $\mathrm{HbAlc}$ of $\leq 7 \%$ were $25.8 \%$ in the EZL group and $31.3 \%$ in the LAN group $(\mathrm{p}=0.0552)$ (Figure 3 ).

There was no difference in the dose of insulin $/ \mathrm{kg} \mathrm{BW} /$ day and the change of BW at the end of the study from baseline between the two groups (Table 4).

\section{Safety Hypoglycemia and Ketoacidosis}

There were six cases of hypoglycemia (SMBG of $<70 \mathrm{mg} / \mathrm{dL}$ ) in patients treated with EZL versus five cases in LAN. One hypoglycemia in the LAN group is 


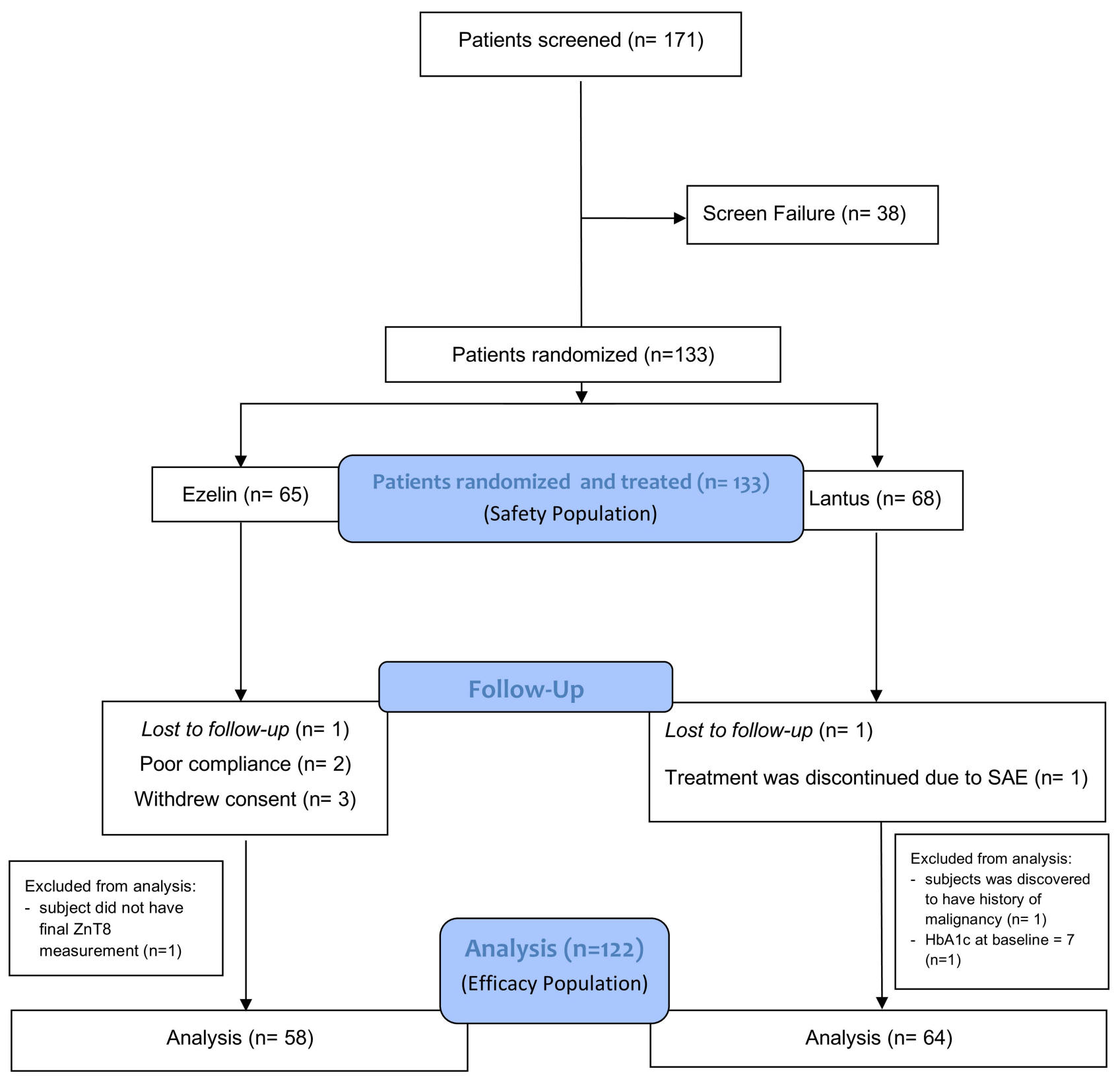

Figure I The flow of patients throughout the study.

categorized as SAEs. However, there were 17 cases of suspected cases of hypoglycemia in the EZL group versus 15 cases in the LAN group, without SMBG measurement. No patient in both groups experienced ketoacidosis during the study.

\section{Adverse Events}

There were 25 cases of non-SAEs (other than hypoglycemia) in the EZL group versus 47 cases in the LAN group reported during 24 weeks of treatment (Table 5). The majority of AEs were mild. In the EZL group, 21/25 cases were considered mild, 4/25 cases were moderate, and none were severe. In the LAN group, 43/48 cases were mild, 4/48 cases were moderate, and none were severe.

\section{Serious Adverse Events}

There were 11 cases of SAEs throughout the study: 4 $(6.1 \%)$ in the EZL group versus $7(10.3 \%)$ in the LAN group (Table 6). There was only one case that was considered possibly related to treatment by the investigator (ie, hypoglycemia) that resulted in hospitalization in the patient treated with LAN. The patient recovered, and the study drug was continued. 
Table I Demography and Baseline Characteristics

\begin{tabular}{|c|c|c|c|c|c|}
\hline & & \multicolumn{2}{|c|}{ Efficacy Population $(N=122)$} & \multicolumn{2}{|c|}{ Safety Population $(\mathrm{N}=\mid 33)$} \\
\hline & & EZL $(n=58)$ & LAN $(n=64)$ & EZL $(n=65)$ & LAN $(n=68)$ \\
\hline Age (year) & Mean (SD) & $55.5(7.61)$ & 57. I (8.35) & $55.4(7.60)$ & $57.7(8.66)$ \\
\hline Men & $\mathrm{n}(\%)$ & $21(36.2)$ & $25(39.1)$ & $23(35.4)$ & $26(38.2)$ \\
\hline Women & $\mathrm{n}(\%)$ & $37(63.8)$ & $39(60.9)$ & $42(64.6)$ & $42(61.8)$ \\
\hline BMI $\left(\mathrm{kg} / \mathrm{m}^{2}\right)$ & Mean (SD) & $26.5(3.84)$ & $25.7(3.47)$ & $26.3(3.83)$ & $25.9(3.66)$ \\
\hline HbAlc (\%) & Mean (SD) & $9.8(1.76)$ & $9.3(1.57)$ & $10.0(1.83)$ & $9.4(1.72)$ \\
\hline Fasting plasma glucose (mg/dL) & Mean (SD) & $176.8(56.60)$ & $175.6(54.60)$ & $183.5(59.45)$ & $\mid 78.7(58.4 \mid)$ \\
\hline 2-hour postprandial blood glucose & Mean (SD) & $250.0(79.43)$ & $243.4(79.47)$ & $258.5(82.89)$ & $245.2(81.23)$ \\
\hline eGFR $\left(\mathrm{mL} / \mathrm{min} / \mathrm{l} .73 \mathrm{~m}^{2}\right)$ & Mean (SD) & $93.9(33.65)$ & $87.8(33.58)$ & $94.7(32.82)$ & $87.5(32.67)$ \\
\hline BUN (mg/dL) & Mean (SD) & $12.9(5.00)$ & $12.8(4.56)$ & $12.8(4.90)$ & $12.8(4.5 \mathrm{I})$ \\
\hline AST (U/L) & Mean (SD) & $21.2(9.89)$ & $21.3(9.67)$ & $21.4(10.46)$ & $20.9(9,56)$ \\
\hline ALT (U/L) & Mean (SD) & $26.4(16.36)$ & $26.4(|8.3|)$ & $26.84(17.98)$ & $25.65(18,07)$ \\
\hline Oral antidiabetic: & n (\%) & & & & \\
\hline Sulfonylurea & & $46(79.3)$ & 51 (79.7) & 51 (78.5) & 55 (80.9) \\
\hline Metformin & & $43(73.1)$ & 51 (79.7) & $49(75.4)$ & 54 (79.4) \\
\hline Acarbose & & $23(39.7)$ & $25(39.1)$ & $26(40.0)$ & 27 (39.7) \\
\hline Pioglitazone & & $4(6.9)$ & $3(4.7)$ & $4(6.2)$ & $3(4.4)$ \\
\hline
\end{tabular}

Abbreviation: SD, standard deviation.

Table 2 Proportions of Patients with a Change from Baseline in IAA and ZnT8

\begin{tabular}{|l|l|l|l|}
\hline & $\begin{array}{l}\text { EZL } \\
(\mathbf{n = 5 8 )}\end{array}$ & $\begin{array}{l}\text { LAN } \\
(\mathbf{n = 6 4 )}\end{array}$ & P \\
\hline $\begin{array}{l}\text { Change from baseline in IAA (from } \\
\text { negative to positive), } \mathrm{n}(\%)\end{array}$ & $\mathrm{I}(\mathrm{I} .7)$ & $\mathrm{I}(\mathrm{I} .6)$ & $\mathrm{I} .000$ \\
\hline $\begin{array}{l}\text { Change from baseline in ZnT8 } \\
\text { autoantibody (from negative to } \\
\text { positive), n (\%) }\end{array}$ & $\mathrm{I}(\mathrm{I.7)}$ & $0(0)$ & 0.475 \\
\hline
\end{tabular}

Abbreviation: IAA, insulin autoantibody.

\section{Discussion}

As a biological product, biosimilar insulin could not be considered as a "generic product." To replace its originator, some requirements must be fulfilled before marketing authorizations, which are similarity in efficacy, safety, and immunogenicity. ${ }^{7,8,12}$ Biopharmaceuticals, biosimilar insulin, in particular, have the potential to cause an immunogenic response, which ultimately may affect the efficacy and safety profile of the drug. The difference in protein products manufactured in living cells can trigger different immune responses, especially
Table 3 Change from Baseline in HbAlc, Fasting Plasma Glucose and 2-Hour Postprandial Glucose After 24-Week Treatment with EZL or LAN

\begin{tabular}{|l|l|l|l|l|}
\hline & $\begin{array}{l}\text { EZL } \\
(\mathbf{n = 5 8 )}\end{array}$ & $\begin{array}{l}\text { LAN } \\
(\mathbf{n = 6 4 )}\end{array}$ & $\begin{array}{l}\text { Mean } \\
\text { Difference }\end{array}$ & \\
\cline { 2 - 5 } & & $\mathbf{9 5 \%} \mathbf{C I}$ & $\mathbf{P}$ \\
\hline $\begin{array}{l}\text { Change from baseline } \\
\text { in HbA Ic (\%), mean } \\
\text { (SD) }\end{array}$ & $\begin{array}{l}-2.0 \\
(\mathrm{I} .60)\end{array}$ & $\begin{array}{l}-1.7 \\
(\mathrm{I} .60)\end{array}$ & $\begin{array}{l}-0.3 \\
(-0.89, \\
0.26)\end{array}$ & 0.276 \\
\hline $\begin{array}{l}\text { Change from baseline } \\
\text { in FPG (mg/dL), mean } \\
\text { (SD) }\end{array}$ & $\begin{array}{l}-67.46 \\
(57.486)\end{array}$ & $\begin{array}{l}-58.1 \mathrm{I} \\
(66.527)\end{array}$ & $\begin{array}{l}-9.4 \\
(-32.30, \\
13.57)\end{array}$ & 0.420 \\
\hline $\begin{array}{l}\text { Change from baseline } \\
\text { in 2hPPG (mg/dL), } \\
\text { mean (SD) }\end{array}$ & $\begin{array}{l}-76.5 \mathrm{I} \\
(86.824)\end{array}$ & $\begin{array}{l}-70.03 \\
(88.486)\end{array}$ & $\begin{array}{l}-6.8 \\
(-38,58, \\
25.62)\end{array}$ & 0.698 \\
\hline
\end{tabular}

Abbreviations: SD, standard deviation; FPG, fasting plasma glucose; 2hPPG, 2-hour postprandial glucose.

in insulin-naïve patients. ${ }^{11}$ Thus, immunogenicity evaluation with a head-to-head comparison with its originator is compulsory. ${ }^{12}$ 

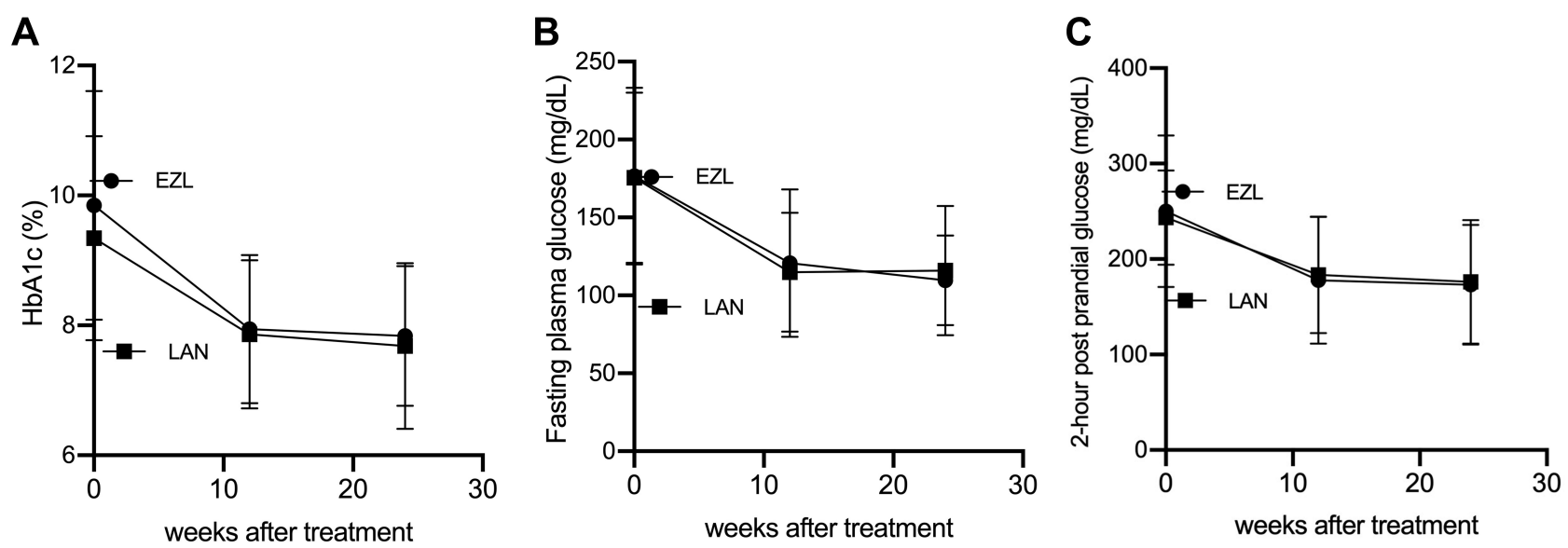

Figure 2 (A) HbA lc, (B) fasting plasma glucose and (C) 2-hour postprandial glucose at baseline, after 12-weeks and 24-weeks of treatment.

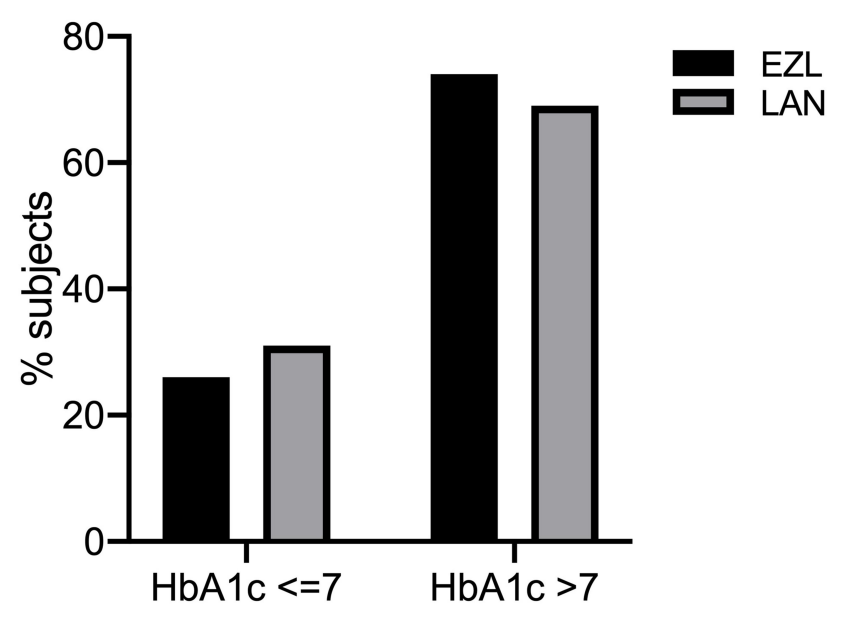

Figure 3 Proportions of patients achieving HbAlc $\leq 7.0 \%$ and $\mathrm{HbAlc}>7$ after $24-$ week treatment with EZL or LAN.

Table 4 The Dose of Insulin/kg BW at the End of the Study, and the Change of Body Weight from Baseline After 24 Weeks of Treatment with EZL or LAN

\begin{tabular}{|l|l|l|l|l|}
\hline & $\begin{array}{l}\text { EZL } \\
(\mathbf{n = 5 8})\end{array}$ & $\begin{array}{l}\text { LAN } \\
(\mathbf{n = 6 4})\end{array}$ & $\begin{array}{l}\text { Mean } \\
\text { Difference } \\
\mathbf{9 5 \%} \mathbf{~ C l}\end{array}$ & $\mathbf{p}$ \\
\hline $\begin{array}{l}\text { The dose of insulin } \\
(\mathrm{U}) / \mathrm{kg} \text { BW at the } \\
\text { end of the study, } \\
\text { mean (SD) }\end{array}$ & $\begin{array}{l}0.28 \\
(0.138)\end{array}$ & $\begin{array}{l}0.25 \\
(0.104)\end{array}$ & $\begin{array}{l}0.035(-0.0080, \\
0.0080)\end{array}$ & 0.109 \\
\hline $\begin{array}{l}\text { Change from } \\
\text { baseline in body } \\
\text { weight (kg), Mean } \\
(\mathrm{SD})\end{array}$ & $\begin{array}{l}2.15 \\
(3.608)\end{array}$ & $\begin{array}{l}2.04 \\
(2.320)\end{array}$ & $\begin{array}{l}0.12(-0.961, \\
1.193)\end{array}$ & 0.831 \\
\hline
\end{tabular}

Table 5 Adverse Events (Other Than Hypoglycemia Reported During 24-Weeks of Treatment with EZL or LAN)

\begin{tabular}{|c|c|c|c|}
\hline Organ System & Adverse Events & $\begin{array}{l}\text { EZL } \\
(n=65)\end{array}$ & $\begin{array}{l}\text { LAN } \\
(n=68)\end{array}$ \\
\hline $\begin{array}{l}\text { Dermato- } \\
\text { musculoskeletal }\end{array}$ & $\begin{array}{l}\text { Dermatitis } \\
\text { Musculoskeletal pain } \\
\text { Peripheral } \\
\text { neuropathy } \\
\text { Osteoarthritis genu } \\
\text { Neck fracture } \\
\text { Hematoma at the } \\
\text { injection site } \\
\text { Edema tibia }\end{array}$ & $\begin{array}{l}2(3.0) \\
I(1.5) \\
\text { I (1.5) } \\
I(1.5) \\
I(1.5) \\
0(0) \\
0(0)\end{array}$ & $\begin{array}{l}3(4.4) \\
3(4.4) \\
4(5.9) \\
0(0) \\
0(0) \\
5(7.4) \\
2(2.9)\end{array}$ \\
\hline $\begin{array}{l}\text { Gastrointestinal } \\
\text { and hepatobiliary }\end{array}$ & $\begin{array}{l}\text { Gastritis } \\
\text { Dyspepsia } \\
\text { syndrome } \\
\text { Diarrhea } \\
\text { Acute } \\
\text { gastroenteritis } \\
\text { Gastroesophageal } \\
\text { reflux disease }\end{array}$ & $\begin{array}{l}5(7.7) \\
3(4.6) \\
I(1.5) \\
I(1.5) \\
0(0)\end{array}$ & $\begin{array}{l}0(0) \\
1(1.5) \\
8(11.7) \\
2(2.9) \\
3(4.4)\end{array}$ \\
\hline Respiratory & $\begin{array}{l}\text { Pulmonary } \\
\text { tuberculosis } \\
\text { Cough } \\
\text { Upper respiratory } \\
\text { tract infection }\end{array}$ & $\begin{array}{l}0(0) \\
1(1.5) \\
2(3.0)\end{array}$ & $\begin{array}{l}\text { I (I.5) } \\
\text { I }(1.5) \\
7(10.3)\end{array}$ \\
\hline Nervous & $\begin{array}{l}\text { Bell's Palsy } \\
\text { Sefalgia } \\
\text { Vertigo }\end{array}$ & $\begin{array}{l}\text { I (I.5) } \\
3(4.6) \\
\text { I (I.5) }\end{array}$ & $\begin{array}{l}0(0) \\
0(0) \\
3(4.4)\end{array}$ \\
\hline Cardiovascular & $\begin{array}{l}\text { Atypical chest pain } \\
\text { Palpitation }\end{array}$ & $\begin{array}{l}0(0) \\
0(0)\end{array}$ & $\begin{array}{l}\text { I (I.5) } \\
3(4.4)\end{array}$ \\
\hline Other & Motorbike accident & $\mathrm{I}(\mathrm{I} .5)$ & $0(0)$ \\
\hline
\end{tabular}


Table 6 Serious Adverse Events Throughout the Study in Patients Treated with EZL or LAN

\begin{tabular}{|c|c|c|c|c|c|}
\hline \multirow[t]{2}{*}{ Serious Adverse Events } & \multicolumn{2}{|c|}{ Treatment } & \multirow{2}{*}{$\begin{array}{l}\text { Effect on } \\
\text { Study Drug }\end{array}$} & \multirow{2}{*}{$\begin{array}{l}\text { Status at } \\
\text { Follow-Up }\end{array}$} & \multirow{2}{*}{$\begin{array}{l}\text { Relationship with } \\
\text { Study Drug }\end{array}$} \\
\hline & $\begin{array}{l}E Z L \\
(N=65)\end{array}$ & $\begin{array}{l}\text { LAN } \\
(\mathbf{N}=68)\end{array}$ & & & \\
\hline Total SAE & $4(6.1 \%)$ & $7(10.3)$ & & & \\
\hline Hypoglycemia & & I ( $(1.4)$ & Continued & Recovered & Possibly related \\
\hline Transient ischemic attack & $\mathrm{I}(\mathrm{I} .5)$ & & Continued & $\begin{array}{l}\text { Recovered with } \\
\text { sequelae }\end{array}$ & Unlikely \\
\hline Neck fracture & $\mathrm{I}(\mathrm{l} .5)$ & & Continued & Permanent & Not related \\
\hline Diabetic ulcer gangrene & $\mathrm{I}(\mathrm{l} .5)$ & & Continued & $\begin{array}{l}\text { Recovered with } \\
\text { sequelae }\end{array}$ & Not related \\
\hline Stroke non-hemorrhagic & & $\mathrm{I}(\mathrm{I} .4)$ & Continued & $\begin{array}{l}\text { Recovered with } \\
\text { sequelae }\end{array}$ & Not related \\
\hline Dyspnea e.c acute lung edema & & I (I.4) & Continued & $\begin{array}{l}\text { Recovered with } \\
\text { sequelae }\end{array}$ & Not related \\
\hline Ketosis diabetic & & $\mathrm{I}(\mathrm{l} .4)$ & Discontinued & $\begin{array}{l}\text { Recovered with } \\
\text { sequelae }\end{array}$ & Not related \\
\hline Unstable angina & & I ( $(1.4)$ & Continued & $\begin{array}{l}\text { Recovered with } \\
\text { sequelae }\end{array}$ & Not related \\
\hline Acute gastroenteritis and acute kidney failure & & $\mathrm{I}(\mathrm{I} .4)$ & Continued & Recovered & Not related \\
\hline Vertigo & $\mathrm{I}(\mathrm{I} .5)$ & $\mathrm{I}(1.4)$ & Continued* & Recovered* & Not related* \\
\hline
\end{tabular}

Note: *Vertigo in patients treated with EZL and LAN, both recovered, drug treatments were continued and both were considered not related.

EZL, a biosynthetic insulin glargine or known as Basalin in its origin country, has a proven similarity in efficacy and safety, based on a previous clinical trial with LAN. ${ }^{9}$ However, up to date, the immunogenicity study of the product versus LAN remains insufficient.

This was an open-label, randomized, comparative, multicenter, 24-week study that aims to prove the similarity of immunogenicity potential of EZL versus LAN. The selected period of study was based on other insulin glargine immunogenicity studies, such as Basaglar and MYL-1501D. ${ }^{13-15}$

This study recruited 133 insulin-naïve patients with T2D from three hospitals across Jakarta, Indonesia. We included patients who were not adequately controlled with oral antidiabetic medications, as proven with $\mathrm{HbA} 1 \mathrm{c}$ of $>7.0 \%$. In this study, patients started insulin mostly at a higher HbA1c level, which was over 9\%. Currently available guidelines from the American Diabetes Association and European Association for the Study of Diabetes recommended that insulin treatment should start when patients failed to achieve HbAlc of $<7.0 \%$, after lifestyle modification and metformin treatment. ${ }^{16}$ In the present study, the majority of patients have received 2-4 oral antidiabetic drugs; however, plasma glucose control remains inadequate. While another study was using insulin, glargine was started at $\mathrm{HbA} 1 \mathrm{c}$ of $8 \%{ }^{13-15,17}$
We used two markers of immunogenicity to exogenous insulin: IAA and ZnT8. ZnT8 is a protein that is highly expressed in beta cells. ZnT8 together with GAD65 and IAA IA-2 can confirm the diagnosis of type 1 diabetes in about $94 \%$ of subject. Together, all the antibodies are associated with specific HLA class II alleles contained within type 1 diabetes risk genotypes. The markers were also used to detect the pancreatic autoimmunity conditions of patients. ${ }^{18,19}$ Previous studies had shown that the monitoring of IAA and ZnT8 would provide autoimmunity data in $96 \%$ of cases. ${ }^{11,19}$ In an insulin glargine study (Basaglar), the total insulin cross-reactive antibodies were used as a marker for autoimmunity. ${ }^{13}$

In the present study, the primary endpoints were the markers of immunogenicity, IAA, and ZnT8 measured at the start and end of trials. Therefore, only patients who completed the study at 24 weeks were analyzed for the primary endpoints $(n=122)$. For hypoglycemic events, AEs and SAEs were analyzed in all randomized patients ( $\mathrm{n}$ = 133). We measured pretreatment ZnT8 and IAA to exclude the presence of diabetes-related autoantibodies of the subjects, while IAA is an autoantibody test that is more sensitively influenced by exogenous insulin treatment. ${ }^{20}$

We found that both drugs, EZL and LAN, had no notable increase in IAA and ZnT8 antibodies after 24 
weeks of treatment. There was only one patient in each group that experienced positive IAA and only one patient in the EZL group that has a positive ZnT8 antibody after treatments. Our result confirmed the similarity of EZL and LAN, concerning their immunogenicity potential.

In the one patient that $\mathrm{ZnT}$ 8 had appeared from negative to positive, we presume that the particular patient might be developing an autoimmune response that might be separate from insulin treatment but rather from the course of the disease development. While there was one patient in each group that experienced an IAA-positive antibody, we assumed that the effect is due to insulin treatment. Studies suggested that the development of IAA might not interfere with insulin action. ${ }^{21}$ However, variable degrees of hypoglycemia might be associated with IAA. ${ }^{22}$

Hypoglycemia is known to be the pitfall that limits the intensification of insulin therapy, making it difficult for a clinician to achieve optimal glycemic control. ${ }^{5,23,24}$ In this study, we found only six cases of hypoglycemia (SMBG of $<70 \mathrm{mg} / \mathrm{dL}$ ) in patients treated with EZL versus five cases in LAN. There were 17 cases of suspected cases of hypoglycemia (patients complained of headache and hyperhidrosis; however, no SMBG measurement was provided) in the EZL group versus 15 cases in the LAN group. The percentage of hypoglycemia in this study was relatively smaller compared to similar studies in Basaglar and MYL-1501D. ${ }^{13,15}$ The incidence of hypoglycemia in MYL-1501D versus LAN in the INSTRIDE-2 study was $27 \%$ versus $23 \%$ during 6 months of therapy, ${ }^{15}$ whereas in the ELEMENT 5 study, Basaglar versus LAN, it was recorded as $23 \%$ versus $35.8 \%{ }^{13}$ Basal insulin, such as glargine, is expected to have a low risk of hypoglycemia. Still, in this study, patients also received sulfonylurea, which had quite high hypoglycemia side effects. Different types of oral antidiabetics used by the subjects were varied, which might affect the incidence of hypoglycemia.

One of the limitations of this study was the method of SMBG, which was done every 3 days or when there was suspicion of hypoglycemia. Various studies and consensus have suggested that the best blood glucose control to achieve the HbAlc target and reduce the incidence of hypoglycemia is to do 7-point SMBG within 24 hours. ${ }^{25-27}$ Although it is important to improve glucose control in SMBG, patients with diabetes use it infrequently due to inconvenience, pain, and economic concern in relation to the cost of blood glucose test strips and lancets. $^{28-30}$
The number of AEs in EZL was lower than in LAN, but it was not statistically significant. We also noted that there were higher proportions of patients who reported the occurrence of hematoma at the injection site (7.4\%), whereas there were none in patients treated with EZL. In our study, investigators have provided the training needed by patients in terms of injection methods at the start of the trial. However, no retraining was provided throughout the study. Several studies have pointed out that, with improved patient educations, the injection site reactions in insulin treatment can be minimized. ${ }^{31} \mathrm{We}$ suggest for post-marketing study to evaluate patient satisfaction in using the insulin pen in a real-life setting. Several studies had described that patient preference and satisfaction on the use of insulin pen devices lead to increased patient compliance. ${ }^{32-34}$ Educators should inform subsequently standardized guidance around insulin including injection sites and method. Incorrect knowledge about insulin injections, for example, needle reuse, of patients with diabetes may lead to lipohypertrophy in the injection area, which increase hypoglycemia risk. ${ }^{34-39}$

The majority of AEs in the present study were mild. There were four events of SAEs in the EZL group and seven SAEs in the LAN group. There was one SAE (diabetic ketosis) in the LAN group, which resulted in the discontinuation of the study drug. Only one SAE was declared possible-related by investigators, namely, the incidence of hypoglycemia (random plasma glucose $=$ $55 \mathrm{mg} / \mathrm{dL}$ ).

EZL also showed a similarity in its efficacy in reducing HbA1c, FPG, and 2hPPG versus LAN. Numerically, EZL lowered $\mathrm{HbAlc}$ more than LAN, which was $2 \%$, while LAN was $1.69 \%$. However, the proportion of patients who achieved optimal HbAlc $(\leq 7 \%)$ was higher in LAN (31.3\%) than in EZL (25.8\%). This is due to the high $\mathrm{HbA} 1 \mathrm{c}$ baseline; therefore, at the end of treatment, glucose control had not been reached.

At the end of treatment, insulin doses $/ \mathrm{kg}$, as well as the change in the BW, in both groups were roughly similar. The results suggested that the potency of the two insulin is similar.

\section{Conclusion}

In conclusion, this study confirms the similarity of insulin glargine EZL in terms of changes in the markers of immunogenicity, efficacy, and safety with its originator. 


\section{Data Sharing Statement}

The data that support the findings of this study are available from the corresponding author, [TJET], upon reasonable request.

\section{Acknowledgments}

Dr. Brian Clement Phandagi, Dr. Endang Prawitasari, Dr. Asmi, Dr. Amelia Putri Santosa, Dr. Marsita Ayu Lestari and Nida Amalina supported in patient recruitment process. The authors would like to thank Enago (www. enago.com) for the English language review.

\section{Funding}

PT Kalbe Farma funded the study; however, the company did not interfere with the conduct of the trial and manuscript writing.

\section{Disclosure}

The authors declare no potential conflict of interest relevant to this study.

\section{References}

1. Brunton S. Pathophysiology of Type 2 Diabetes: the Evolution of Our Understanding.. J Fam Pract. 2016;65(4 Suppl):supp_az_0416.

2. Shah VN, Moser EG, Blau A, Dhingra M, Garg SK. The future of basal insulin. Diabetes Technol Ther. 2013;15(9):727-732. doi:10.1089/dia.2013.0228

3. Hemraj F, Garces K. Insulin glargine for type 2 diabetes. Issues Emerg Health Technol. 2004;59:1-4.

4. Schreiber SA. Insulin glargine in type 2 diabetes in everyday clinical practice: 7 years experience. Diab Obes Metab. 2008;10(Suppl s2):24-34. doi:10.1111/j.1463-1326.2008.00842.x

5. Owens DR. Clinical evidence for the earlier initiation of insulin therapy in type 2 diabetes. Diabetes Tech Ther. 2013;15 (9):776-785. doi:10.1089/dia.2013.0081

6. Xu Y, Sun L, Anderson M, et al. Insulin glargine and its two active metabolites: A sensitive (16 pM) and robust simultaneous hybrid assay coupling immunoaffinity purification with LC-MS/MS to support biosimilar clinical studies. J Chromatogr B. 2017;1063:50-59. doi:10.1016/j.jchromb.2017.08.018

7. Heinemann L, Home PD, Hompesch M. Biosimilar insulins: guidance for data interpretation by clinicians and users. Diab Obes Metab. 2015;17(10):911-918. doi:10.1111/dom.12491

8. Yamada T, Kamata R, Ishinohachi K, et al. Biosimilar vs originator insulins: systematic review and meta-analysis. Diab Obes Metab. 2018;20(7):1787-1792. doi:10.1111/dom.13291

9. Li HQ, Lu CF, Wang J, et al. A comparison of clinical efficacy and economic value in Basalin- and Lantus-treated patients with type 2 diabetes using continuous glucose monitoring system. $J$ Endocrinol Invest. 2018;41(2):179-184. doi:10.1007/s40618-017-0712-0

10. Tieu C, Lucas EJ, DePaola M, Rosman L, Alexander GC, Sethi JK. Efficacy and safety of biosimilar insulins compared to their reference products: A systematic review. PLoS One. 2018;13(4):e0195012. doi:10.1371/journal.pone.0195012

11. Pineda C, Castaneda Hernandez G, Jacobs IA, Alvarez DF, Carini C. Assessing the Immunogenicity of Biopharmaceuticals. BioDrugs. 2016;30(3):195-206. doi:10.1007/s40259-016-0174-5
12. DeVries JH, Gough SC, Kiljanski J, Heinemann L. Biosimilar insulins: a European perspective. Diab Obes Metab. 2015;17(5):445-451. doi:10.1111/dom. 12410

13. Pollom RK, Ilag LL, Lacaya LB, Morwick TM, Ortiz Carrasquillo R. Lilly Insulin Glargine Versus Lantus ${ }^{\circledR}$ in Insulin-Naïve and InsulinTreated Adults with Type 2 Diabetes: A Randomized, Controlled Trial (ELEMENT 5). Diabetes Therapy. 2019;10(1):189-203. doi:10.1007/s13300-018-0549-3

14. Pollom RK, Costigan T, Lacaya LB, Ilag LL, Hollander PA. Similar Efficacy and Safety of Basaglar((R)) and Lantus((R)) in Patients with Type 2 Diabetes in Age Groups ( $<65$ Years, $>/=65$ Years): A Post Hoc Analysis from the ELEMENT-2 Study. Diab Ther. 2018;9 (2):827-837.

15. Blevins TC, Barve A, Sun B, et al. Efficacy and safety of MYL-1501D versus insulin glargine in patients with type 2 diabetes after 24 weeks: results of the Phase III INSTRIDE 2 study. Diab Obes Metab. 2019;21(1):129-135. doi:10.1111/dom.13495

16. Nathan DM, Buse JB, Davidson MB, et al. Medical management of hyperglycemia in type 2 diabetes: a consensus algorithm for the initiation and adjustment of therapy: a consensus statement of the American Diabetes Association and the European Association for the Study of Diabetes. Diab Care. 2009;32(1):193-203. doi:10.2337/dc08-9025

17. Rosenstock J, Hollander P, Bhargava A, et al. Similar efficacy and safety of LY2963016 insulin glargine and insulin glargine $(\operatorname{Lantus}(\mathrm{R}))$ in patients with type 2 diabetes who were insulin-naive or previously treated with insulin glargine: a randomized, double-blind controlled trial (the ELEMENT 2 study). Diab Obes Metab. 2015;17(8):734-741.

18. Wenzlau JM, Frisch LM, Hutton JC, et al. Changes in Zinc Transporter 8 Autoantibodies Following Type 1 Diabetes Onset: the Type 1 Diabetes Genetics Consortium Autoantibody Workshop. Diab Care. 2015;38(Suppl Supplement 2):S14-S20. doi:10.2337/dcs152004

19. Wenzlau JM, Hutton JC. Novel diabetes autoantibodies and prediction of type 1 diabetes. Curr Diabetes Rep. 2013;13(5):608-615. doi:10.1007/s11892-013-0405-9

20. Fineberg SE, Kawabata TT, Finco-Kent D, et al. Immunological responses to exogenous insulin. Endocr Rev. 2007;28(6):625-652.

21. Hu X, Chen F. Exogenous insulin antibody syndrome (EIAS): a clinical syndrome associated with insulin antibodies induced by exogenous insulin in diabetic patients. Endocr Connect. 2018;7(1): R47-R55. doi:10.1530/EC-17-0309

22. Ismail AA. The insulin autoimmune syndrome (IAS) as a cause of hypoglycaemia: an update on the pathophysiology, biochemical investigations and diagnosis. Clin Chem Lab Med. 2016;54 (11):1715-1724. doi:10.1515/cclm-2015-1255

23. Banerji MA, Baron MA, Gao L, Blonde L. Influence of baseline glycemia on outcomes with insulin glargine use in patients uncontrolled on oral agents. Postgrad Med. 2014;126(3):111-125. doi:10.3810/pgm.2014.05.2761

24. Clements JN, Threatt T, Ward E, Shealy KM. Clinical Pharmacokinetics and Pharmacodynamics of Insulin Glargine 300 U/mL. Clin Pharmacokinet. 2017;56(5):449-458. doi:10.1007/ s40262-016-0464-6

25. Czupryniak L, Barkai L, Bolgarska S, et al. Self-Monitoring of Blood Glucose in Diabetes: from Evidence to Clinical Reality in Central and Eastern Europe-Recommendations from the International CentralEastern European Expert Group. Diabetes Techn Therapeutics. 2014;16(7):460-475. doi:10.1089/dia.2013.0302

26. Kirk JK, Stegner J. Self-monitoring of blood glucose: practical aspects. J Diabetes Sci Tech. 2010;4(2):435-439. doi:10.1177/ 193229681000400225

27. Clar C, Barnard K, Cummins E, Royle P, Waugh N. Selfmonitoring of blood glucose in type 2 diabetes: systematic review. Health Technol Asses. 2010;14(12):1-140. doi:10.3310/ hta 14120 
28. American Diabetes Association. 6. Glycemic Targets: standards of Medical Care in Diabetes-2018. Diab Care. 2018;41(Suppl Supplement 1):S55-S64. doi:10.2337/dc18-S006

29. Song YS, Koo BK, Kim SW, Yi KH, Shin K, Moon MK. Improvement of glycosylated hemoglobin in patients with type 2 diabetes mellitus under insulin treatment by reimbursement for self-monitoring of blood glucose. Diabetes Metab J. 2018;42 (1):28-42. doi:10.4093/dmj.2018.42.1.28

30. Young LA, Buse JB, Weaver MA; Monitor Trial Group. Glucose Self-monitoring in Non-Insulin-Treated Patients With Type 2 Diabetes in Primary Care Settings. JAMA Intern Med. 2017;177 (7):920-929. doi:10.1001/jamainternmed.2017.1233

31. Richardson T, Kerr D. Skin-related complications of insulin therapy: epidemiology and emerging management strategies. Am J Clin Dermatol. 2003;4(10):661-667. doi:10.2165/00128071-20030410000001

32. Kreugel G, Keers JC, Kerstens MN, Wolffenbuttel BHR. Randomized trial on the influence of the length of two insulin pen needles on glycemic control and patient preference in obese patients with diabetes. Diabetes Technol Ther. 2011;13(7):737-741. doi:10.1089/dia.2011.0010

33. Berard L, Cameron B, Woo V. Pen needle preference in a population of Canadians with diabetes: results from a recent patient survey. Can J Diabetes. 2015;39(3):206-209. doi:10.1016/j.jcjd.2014.09.008

34. Bari B, Corbeil M-A, Farooqui H, et al. Insulin Injection Practices in a Population of Canadians with Diabetes: an Observational Study. Diabetes Ther. 2020;11(11):2595-2609. doi:10.1007/s13300-02000913-y
35. Myers AK, Gulati N, Pascarelli B, et al. Perceptions of Insulin Pen Use and Technique in Black and Hispanic/Latino Patients with Type 2 Diabetes: a Qualitative Study. J Racial Ethnic Health Disparities. 2020;7(5):949-957. doi:10.1007/s40615-020-00718-6

36. Gorska-Ciebiadaa M, Masierek M, Ciebiadac M. Improved insulin injection technique, treatment satisfaction and glycemic control: results from a large cohort education study. $J$ Clin Transl Endocrinol. 2020;19:1-6.

37. Upsher R, Allen-Taylor M, Reece I, et al. Experiences of Attending Group Education to Support Insulin Initiation in Type 2 Diabetes: A Qualitative Study. Diabetes Therapy. 2020;11(1):119-132. doi:10.1007/s13300-019-00727-7

38. Li F, Fu SM, Liu ZP, Liu XR, Hu CJ, Li QF. Injection sites lipohypertrophy among 736 patients with type 2 diabetes of different-grade hospitals. Int J Clin Exp Med. 2016;9(7):13178-13183.

39. Hermanns N, Ehrmann D, Schall S, Maier B, Haak T, Kulzer B. The effect of an education programme (MEDIAS 2 BSC) of non-intensive insulin treatment regimens for people with Type 2 diabetes: a randomized, multi-centre trial. Diabetic Med. 2017;34(8):1084-1091. doi:10.1111/dme.13346

\section{Publish your work in this journal}

Diabetes, Metabolic Syndrome and Obesity: Targets and Therapy is an international, peer-reviewed open-access journal committed to the rapid publication of the latest laboratory and clinical findings in the fields of diabetes, metabolic syndrome and obesity research. Original research, review, case reports, hypothesis formation, expert opinion and commentaries are all considered for publication. The manuscript management system is completely online and includes a very quick and fair peer-review system, which is all easy to use. Visit http://www.dovepress.com/testimonials.php to read real quotes from published authors.

Submit your manuscript here: https://www.dovepress.com/diabetes-metabolic-syndrome-and-obesity-targets-and-therapy-journal 